\title{
Analysis of scientific production on Zika virus and pregnancy
}

\author{
Análise da produção científica sobre Zika vírus e gravidez
}

Luana Kelle Batista Moura ${ }^{1,2}$, Sarah Maria Melo Cordeiro ${ }^{1}$, Camila Aparecida Pinheiro Landim Almeida ${ }^{1}$, Maria do Céu Mendes Pinto Marques ${ }^{3}$, Telma Maria Evangelista de Araújo ${ }^{4}$, Maria Eliete Batista Moura ${ }^{4}$

Objective: to analyze the international scientific production on Zika virus and pregnancy. Methods: a bibliometric survey was carried out in the ISI Web of Knowledge/Web of Science database, using the search terms "Pregnancy", "ZikV" and "Bibliometrics", from the export of this data to the HistCite ${ }^{\mathrm{TM}}$ bibliometric analysis software. Results: 355 publication records were identified and the 11 most cited articles were selected in the Web of Science (global) and those most cited in the selected articles (local) in 207 different journals indexed to the database in question, written by 2,435 authors who had links with 799 institutions, located in 59 countries. Conclusion: obscure aspects remain about the natural history of Zika virus in pregnant women, clinical profile, epidemiology, and lack clarity about the existence of cofactors associated with infection by Zika virus.

Descriptors: Pregnancy; Zika Virus; Bibliometrics.

Objetivo: analisar a produção científica internacional sobre o Zika vírus e a gravidez. Métodos: pesquisa bibliométrica realizada na base de dados ISI Web of Knowledge/Web of Science, com os termos de busca "Pregnancy", "ZikV" e "Bibliometrics, efetuada a partir da exportação destes dados para o software de análise bibliométrica HistCite ${ }^{\mathrm{TM}}$. Resultados: foram identificados 355 registros de publicação e selecionados os 11 artigos mais citados na Web of Science (global) e aqueles mais citados no conjunto de artigos selecionados (local), em 207 periódicos distintos indexados à base de dados em questão, escritos por 2.435 autores que possuíam vínculos com 799 instituições, localizadas em 59 países. Conclusão: persistem aspectos obscuros sobre a história natural do Zika vírus em gestantes, o perfil clínico, a epidemiologia, e falta clareza sobre a existência de cofatores associados à infecção pelo Zika vírus.

Descritores: Gravidez; Zika Virus; Bibliometria.

\footnotetext{
${ }^{1}$ Centro Universitário UNINOVAFAPI. Teresina, PI, Brazil.

${ }^{2}$ Universidade Federal do Rio Grande do Norte. Natal, RN, Brazil

${ }^{3}$ Universidade de Évora, Escola Superior de Enfermagem de São João de Deus. Évora, Portugal.

${ }^{4}$ Universidade Federal do Piauí. Teresina, PI, Brazil.
} 


\section{Introduction}

The Zika virus infection presents itself as a recurring public health problem throughout the world. The World Health Organization has announced the convening of an International Committee for Regulation of Health Emergencies, in the face of an estimated 3 to 4 million new cases of fever caused by the virus in the world, in addition to the strong suspicion of its relation with cases of microcephaly and neurological syndromes ${ }^{(1)}$.

The introduction and dissemination of Zika virus in Brazil was sufficient for the Ministry of Health and the World Health Organization to establish a state of emergency in the country's public health. This condition provoked intense mobilization of states and municipalities to combat viral circulation, requiring a broad intervention policy, involving several sectors of society ${ }^{(2)}$.

Epidemiological surveillance in 2016 reported 6,480 cases of Zika virus in Brazil; of these, 1,349 were discarded and 863 confirmed for microcephaly or changes suggestive of congenital infection caused by the virus. In 97 cases, the presence of the virus was confirmed by specific tests in pregnant or aborting women ${ }^{(3)}$.

In 2018, 4,571 probable cases of the disease were recorded in Brazil, with an incidence rate of 2.2 cases/100 thousand inhabitants; of these, 1,674 were confirmed. The Southeast Region presented the highest number of probable cases in relation to the total of the country. Next, the Northeast, Central-West, North and South Regions appear. In 2017, a death was confirmed by Zika virus in the State of Rondônia and, in 2018, a death in the state of Paraíba. In relation to pregnant women in the country, 869 probable cases were recorded, of which 330 were confirmed by epidemiological or laboratorial clinical criteria ${ }^{(4)}$.

In this context, it is pertinent that the scientific production of studies on the subject be amplified. Considering that bibliometric research ${ }^{(5)}$ aims to contribute to the evolution of knowledge about the researched subject, we have as questions that guide the study: What are the sources of value about Zika viruses recognized by means of authoring and citation metrics? What is the analysis and how were the indicators constructed on the dynamics and evolution of scientific and technological information on the virus?

This study aimed to analyze the international scientific production on Zika virus and pregnancy.

\section{Methods}

This is a bibliometric research carried out in the ISI Web of Knowledge/Web of Science database. Its applicability is an important technique of data collection and analysis, being a pertinent and argumentative source in the search for resources and investments in research in the academic world ${ }^{(5)}$.

The steps for data analysis followed three procedures: definition of the database to be consulted; determination of the criteria to be used for data collection; and definition of the representation and analysis of the data collected. The search period available in the database for full years (1945-2017) was used in order to allow the replication or updating of this study without the need to perform it again from its beginning(5).

The descriptors were defined from the Health Sciences Descriptors catalog, with the following search terms being selected: "Pregnancy", "Zika Virus" and "Bibliometrics". The quotation marks indicate the exact representation of the terms with more than one word.

The collection was carried out from the search of these terms, which represent the title of the articles, abstracts, keywords of the author and keywords created (keywords plus). After the search, a refinement was made of the works found, through the application of filters offered by the base search engine. There was no refinement filter for knowledge areas, countries or study languages, covering all records of publications that had the three terms in association. The articles were excluded from the results, or they were still con- 
sidered in conference proceedings and records from proceedings, editorial material and letter, considering only final and complete papers of the article and review types.

Subsequently, the material was analyzed by exporting the data to the HistCite bibliometric analysis software package in order to organize information and facilitate analysis. The following items were analyzed: the trajectory of annual evolution of the publications; the journals with the greatest number of records; the authors with more publications; and the number of articles distributed by author's country of origin. In addition to these data generated by the software, aspects of the 11 most cited articles globally according to the Global Citation Score (GCS) were elucidated, represents the overall citation of the 11 main articles on the subject, which received the largest number of citations in the Web of ScienceTM and the 11 locally cited articles, according to the Local Citation Score (LCS), which represents the quotient of local citation corresponding to the 11 articles on the theme that received the largest number of citations of the articles selected, in order to identify their main contributions to the related theme the Zika virus and pregnancy.

The ethical principles recommended for research of this nature were adopted, respecting the ideas, quotations, authors and their publications.

\section{Results}

The search conducted for the period from 1945 to 2017 identified the first article result published in 2014 , and for that reason, the time period evaluated in the results from 2014 to 2017.

A total of 355 articles were identified that included the descriptors related to the research. These articles were published in 207 different journals indexed to the database in question and were written by 2,435 authors who had links with 799 research institutions located in 59 countries. To achieve these articles, 7,994 references were used, with an average of approximately 23 references per article.
The evolution of scientific production on Zika virus related to pregnancy, demonstrated by the annual number of publications in the period studied, pointed out that international interest in the subject began in 2014 with the publication of a study. From that year, studies increased, with 138 studies published in 2016 and 216 studies in 2017.

In order to identify the most representative international journals in the Zika virus and pregnancy research area, the 355 journals were analyzed in terms of the number of articles published on the topic and the total number of citations. Table 1 shows the list of the most representative journals considering the number of publications on the topic. The relationship between the number of citations and the number of articles published in each of the journals set up an indicator of the impact of the articles identified in these journals under the total number of citations received.

Table 1 - Periodicals with more articles published (2014-2017)

\begin{tabular}{lccc}
\hline Newspapers & $\begin{array}{c}\text { No of } \\
\text { articles }\end{array}$ & Citations & $\begin{array}{c}\text { Citations/ } \\
\text { Amount }\end{array}$ \\
\hline $\begin{array}{l}\text { Morbidity and Mortality Weekly } \\
\text { Report }\end{array}$ & 9 & 228 & 25.33 \\
Obstetrics \& Gynecology & 9 & 75 & 8.33 \\
$\begin{array}{l}\text { American Journal of Reproductive } \\
\text { Immunology }\end{array}$ & 7 & 33 & 4.71 \\
$\begin{array}{l}\text { Emerging Infectious Diseases } \\
\text { Frontiers in Microbiology }\end{array}$ & 7 & 90 & 12.86 \\
Scientific Reports & 6 & 18 & 3 \\
Seminars in Reproductive Medicine & 6 & 38 & 6.33 \\
Cell Host \& Microbe & 6 & 34 & 5.67 \\
Cell Reports & 5 & 237 & 47.4 \\
Clinical Infectious Diseases & 5 & 87 & 17.4 \\
\hline
\end{tabular}

The journals with the highest number of publication records were the Morbidity and Mortality Weekly Report, which obtained 228 citations, and Obstetrics \& Gynecology, which obtained 75 citations, both with nine articles published. However, to identify those journals with greater impact, an index 
was defined based on the division of the number of citations by the number of published works, presenting Cell Host \& Microbe as the one with the highest index (47.4). This information becomes relevant for researchers and research centers in the area, by mapping the academic journals that publish the most in the subject and more are citations from other studies, considered the articles of greatest Impact Factor on the subject.

The authors who had the most publications on the subject, their institutional link and the country of origin of the institution were presented in Table 2. Among the authors with the largest number of publications on the topic in the Web of Science were Jamieson DJ, with 15 publications, Honein MA with 13, and Diamond MS, with 11; the first two authors belonged to the same institution, the National Center for Chronic Disease Prevention and Health (CDC), and the third belonged to the University of Washington.

Table 2 - Authors with the highest number of publications (2014-2017)

\begin{tabular}{|c|c|c|c|}
\hline Authors & $\begin{array}{c}\text { № of } \\
\text { articles }\end{array}$ & Bond institution & Country \\
\hline Jamieso DJ & 15 & $\begin{array}{c}\text { National Center for Chronic } \\
\text { Disease Prevention and Health }\end{array}$ & U.S \\
\hline Honein MA & 13 & $\begin{array}{c}\text { National Center for Chronic } \\
\text { Disease Prevention and Health }\end{array}$ & U.S \\
\hline Diamond MS & 11 & University of Washington & U.S \\
\hline Meaney-Delman D & 9 & $\begin{array}{c}\text { National Center for Chronic } \\
\text { Disease Prevention and Health }\end{array}$ & U.S \\
\hline Cao B & 8 & University of Washington & U.S \\
\hline Mysorekr IU & 8 & University of Washington & U.S \\
\hline Brasil P & 7 & $\begin{array}{l}\text { Oswaldo Cruz Foundation/Mato } \\
\text { Grosso do Sul }\end{array}$ & Brazil \\
\hline Moore CA & 7 & $\begin{array}{l}\text { Diagnostic Center for } \\
\text { Ultrasound and Imaging }\end{array}$ & Colombia \\
\hline Oduyeb T & 7 & $\begin{array}{c}\text { National Center for Chronic } \\
\text { Disease Prevention and Health }\end{array}$ & U.S \\
\hline Belfort R & 6 & $\begin{array}{l}\text { Universidade Federal de São } \\
\text { Paulo }\end{array}$ & Brazil \\
\hline
\end{tabular}

The United States had the largest number of publications, with 203 articles, and they were the linking country of the most cited authors. It is important to note that Brazil appeared in second place, with 82 articles published.

The classification of the scientific studies by the number of citations received showed works that were considered fundamental to the theme and, although it took some time until the articles began to be cited by other researchers, the evaluation of the citations one tried to establish the state of the art in the area of research on Zika virus and pregnancy, based on the articles that had in the title of the work the terms used in the searches and indexed in one of the journals with the highest amount of citations in the theme.

Figure 1 shows the relationship between the most cited articles, separating them into two groups: (I) articles that received more quotations from other works throughout the ISI Web of Science GCS database and (II) articles that received more quotations of the work of the selection group of this bibliometric LCS study. The number of citations and citation relationships between these works (represented by lines connecting the circles) indicate the most representative studies on the subject, presenting seminal and subsequent works, which were also much referenced.

With these criteria, 11 articles were selected, which were analyzed with the Historiograph/HistCite tool, through which it was possible to identify the articles that are related to each other, mainly due to the references used and/or cited, in which each "circle" represents an article, whose number identifies the work (author/s, year); each "arrow" shows the links between the articles, and the direction of the arrows indicates the relationship between the work and a later study that quotes it. Through this graphic representation, the time line and the main articles of the studied theme were delimited: (1.) Besnard et al. (2014); (2.) Mlakar et al. (1992); (3.) Bayer et al. (2016); (4.) Brasil et al. (2000); (5.) Faria et al. (2016); (6.) Miner et al. (2016); (7.) Franca et al. (2016); (8.) Cauchemez et al. (2016); (9.) Driggers et al. (2016); (10.) Calvet et al. (2016) ; (11.) Yockey et al. (2002). 

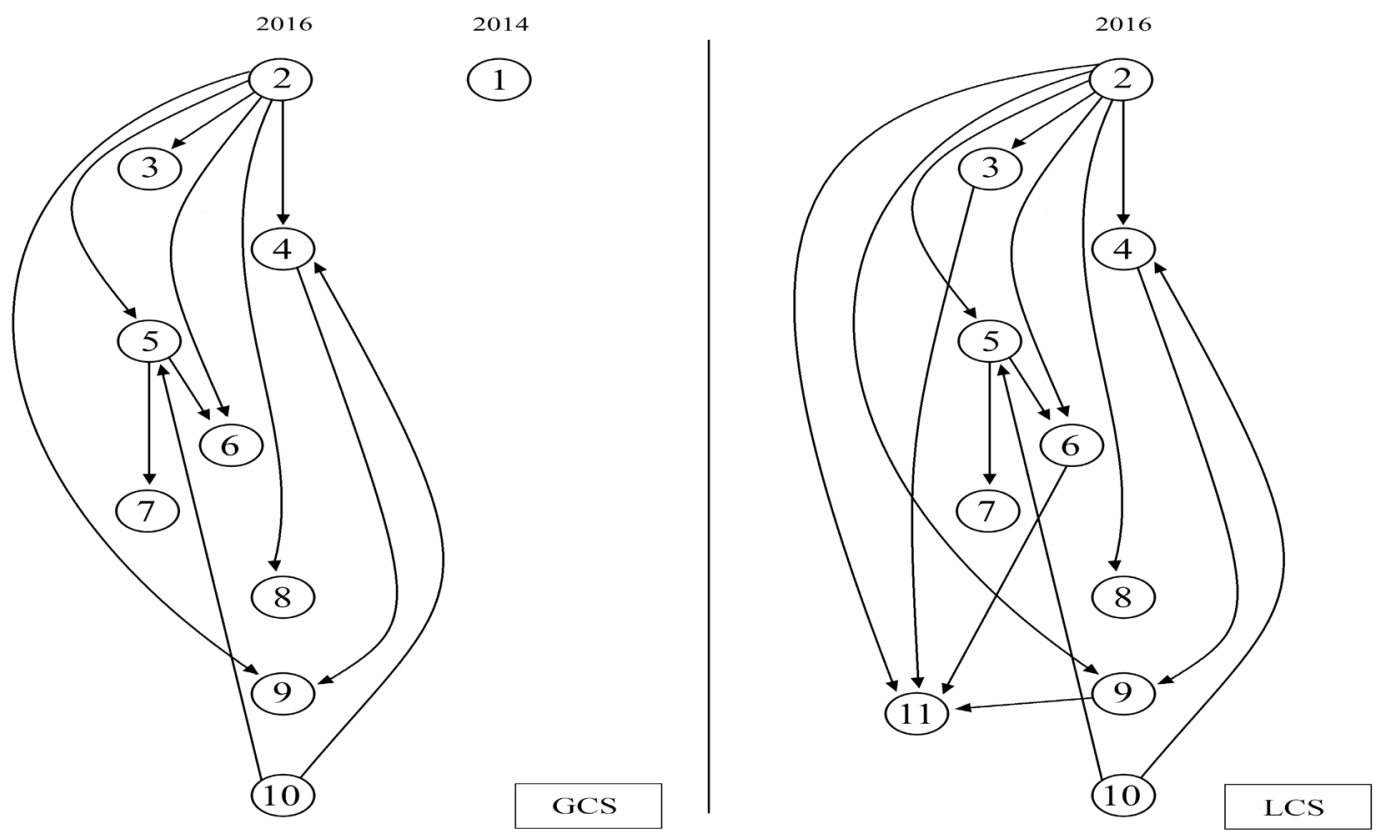

Figure 1 - Top 11 most cited articles in the Web of Science ${ }^{\mathrm{TM}}$ Global Citation Score (GCS), among the selected set

\section{Discussion}

This study has limitations. One is the use of a single database, the Web of Science. In view of the above, it is important to consider that there are few findings in this database that address the correlation of the Zika virus and pregnancy in the public health context.

For the 11 most cited journals, Morbidity and Mortality Weekly Report and Obstetrics \& Gynecology, have the largest number of publications - nine publications each. However, Cell Host \& Microbe has five publications and 237 citations, which considerably increases its Impact Factor in relation to the topic studied, since the amount of citations the journal obtained can serve as an indicator of the relevance of the works.

With regard to the most representative authors and institutions on the subject, the most cited authors are gathered in only three countries, most notably the United States, with 71 publications; a sum of articles larger than the other countries combined. Jamieson DJ published 15 articles on the subject and Honein MA,
13 articles. These authors belong to the CDC, based in DeKalb County, Georgia. Diamond MS has published 11 articles and belongs to Washington University, both in the United States of America.

In this list, Brazilian researchers or Brazilians linked to Brazilian institutions appear, adding seven published articles, pointing to the scarcity of publications in Brazil on the subject studied in journals indexed by the Web of Science, which indicates a gap in the locus representing the knowledge base of that country.

The relationship between the articles in Figure 1 identified the numbers $1^{(6)}$ and $2^{(7)}$ considered in the literature as "authority articles" or "base articles", that is, the main references for other authors, who also receive large quantities of quotations.

In addition to the figure of authority articles, there are also the "hub" or "connecting articles", which condense important information from previous works, connecting them to more recent ones, as well as receiving large amounts of citations, being identi- 
fied by numbers $1^{(6)}, 2^{(7)}, 7^{(8)}, 8^{(9)}$ and $9^{(10)}$.

The first article about the proposed theme was evidenced in 2014, study number $1^{(6)}$, which was considered authoritative article in the relation shown in Figure 1, in the global scope. This study verified the outbreak of Zika virus that occurred in 2013 and 2014 , with about $11.0 \%$ of the Polynesian population contaminated with the virus. This study identified, diagnosed and described two cases of puerperal and their newborns who contracted the Zika virus in pregnancy and transmitted the disease via placental or during childbirth, recommending specialized care for mothers and children, since in this period studies were still very limited. Study number $2^{(7)}$ showed a pregnant woman who presented febrile illness with eruption at the end of the first trimester and at 29 weeks' gestation, microcephaly was diagnosed in the fetus after gestational ultrasound. After gestational discontinuation, the autopsy of the fetus showed the presence of the Zika virus in the brain tissue of the fetus.

The isolated occurrence of microcephaly does not always represent motor or mental changes. Children with below-average head circumference (term newborns with cephalic perimeter less than $31.9 \mathrm{~cm}$ for boys and less than $31.5 \mathrm{~cm}$ for girls) may be cognitively normal, especially if they are of family origin. However, most cases of microcephaly are accompanied by motor and cognitive changes that vary according to the degree of brain involvement. In general, children have a significant delay in neural psychomotor and cognitive development, and in some cases, sensory functions (hearing and vision) are also compromised. Cognitive deficit occurs in about $90.0 \%$ of cases $^{(11)}$. These isolated occurrences of microcephaly can lead to modifications in the structure, functioning and/or metabolism of cells in the brain tissue ${ }^{(12)}$.

Study number $7^{(8)}$ aimed to describe the clinical, anthropometric and survival data of newborns from Brazil during the outbreak of Zika virus considered as suspected cases of congenital virus infection, notified to the Ministry of Health in 2016. The inves- tigations of 1,501 suspected cases, of which 899 were discarded. Of the remaining 602 cases, 76 were definite, 54 highly probable, 181 moderately probable, and 291 somewhat probable Zika virus congenital syndrome. Clinical, anthropometric and survival differences were small among the four groups.

The analysis of an outbreak of Zika virus in Polynesia from 2013 to 2014 identified eight cases of microcephaly and concluded that there was a direct relationship with the infection in the first trimester of pregnancy, according to study number $8^{(9)}$.

The follow-up of a pregnant woman infected with the Zika virus at the 11th week of gestation was presented in study $9^{(10)}$, showing the evolution of the infected fetus and the main brain abnormalities, which, throughout pregnancy, were happening. After fetal death, the virus was identified in brain tissues.

It is important to emphasize that the surveillance system should focus on detecting the congenital syndrome of infection and should not focus only on the presence of microcephaly or on reporting exanthema in pregnancy ${ }^{(13)}$.

In the hub or connecting article, $3^{(14)}$ investigated infection of primary human trophoblast, which are placental barrier cells, finding that these placenta cells are refractory to infection by the virus, and that infection occurs because the virus uses alternative strategies to cross the placental barrier.

Article $4^{(15)}$ investigated pregnant women who presented symptomatology in the gestational period, with or without positive serology, monitoring the fetuses. Among 42 women positive for Zika virus, $12 \mathrm{fe}-$ tuses had intrauterine death, ventricular calcification or other central nervous system abnormalities and abnormal volume of amniotic fluid.

Study $5^{(16)}$ provided a brief summary of the epidemics in Polynesia and Brazil, briefly explaining the genetics of the virus and showing that the per capita relation is not expressive in other population groups, but, it is highly expressive, considered suspect cases in pregnant women up to 14 weeks as microcephaly and severe malformation. 
It is important to clarify that Zika virus infection is asymptomatic in approximately $80 \%$ of infected persons, affects all age groups and both sexes, and is characterized by an acute and self-limiting febrile disease, which was not associated with complications until reaching the pregnant women ${ }^{(17)}$.

Study $6^{(18)}$ show the behavior of Zika virus in rats. After crossing and fertilization, the virus was introduced into pregnant females, resulting in fetal death. The virus was identified within maternal and fetal placental trophoblasts, suggesting trans placental infection and blocking of signaling antibodies in pregnant rats.

Study $10^{(19)}$ aimed to detect and sequence the Zika virus genome in amniotic fluid samples from two Brazilian pregnant women, whose fetuses were diagnosed with microcephaly. As a result, they detected the genome in the amniotic fluid of both pregnant women, and the main result was phylogenetic analysis, showing that the virus shared 97 to $100.0 \%$ of its genomic identity with lineages isolated during an outbreak in Polynesia in 2013 and discarded the hypothesis that the Brazilian genome of the virus was a recombinant mosquito-transmitted flavivirus strain. In this investigation, the reanalysis of the epidemic data in French Polynesia (2013-2014) was confirmed to identify the virus in fetuses with microcephaly and in the amniotic fluid of the mother, confirming the association and estimating a risk of microcephaly of $1.0 \%$ of children of pregnant women infected with the virus.

According to study $11^{(20)}$, the introduction of Zika virus into the vaginal canal of pregnant mice led to high virus replication and severe malformation in fetuses, concluding that sexual transmission was confirmed.

\section{Conclusion}

The sources of value on the Zika virus and pregnancy recognized through authoring and citation metrics were 11 studies out of 355 articles published in 207 distinct journals indexed in the Web of Science written by 2,435 authors who have links to 799 research institutions, located in 59 countries. The analysis of the studies, according to indicators on the dynamics and evolution of scientific and technological information, showed that obscure aspects of the natural history of the Zika virus in pregnant women persist, clinical profile, epidemiological aspects and lack of clarity about the existence of cofactors associated with the infection.

\section{Collaborations}

Moura LKB and Cordeiro SMM contributed to the design, analysis and interpretation of data. Almeida CAPL, Marques MCMP, Araújo TME and Moura MEB contributed to the writing of the article, critical review of the intellectual content and final approval of the version to be published.

\section{References}

1. Henriques CMP, Duarte E, Garcia LP. Desafios para o enfrentamento da epidemia de microcefalia. Epidemiol Serv Saúde. 2016; 25(1):7-10. doi: 10.5123/S1679-49742016000100001

2. Donalisio MR, Freitas ARR, Zuben APBV. Arboviruses emerging in Brazil: challenges for clinic and implications for public health. Rev Saúde Pública. 2017; 51(30):1-6. doi: https://doi.org/10.1590/ S1518-8787.2017051006889

3. Diniz D. Vírus Zika e mulheres. Cad Saúde Pública. 2016; 32(5):1-4. doi: dx.doi.org/10.1590/0102$311 \times 00046316$

4. Ministério da Saúde (BR). Monitoramento dos casos de dengue, febre de chikungunya e doença aguda pelo vírus Zika até a Semana Epidemiológica 23 de 2018 [Internet]. 2018 [citado 2018 Fev. 5]; 49(31):1-14. Disponível em: http://portalarquivos2.saude.gov.br/images/pdf/2018/julho/06/ Monitoramento-dos-casos-de-dengue-23-018.pdf

5. Moura LKB, Mesquita RF, Mobin M, Matos FTC, Monte TL, Lago EC, et al. Uses of bibliometric techniques in public health research. Iran J Public Health [Internet]. 2017 [cited 2018 Mar. 23]; 46(10):1435-6. Available from: https:// europepmc.org/articles/pmc5750357 
6. Besnard M, Lastère $\mathrm{S}$, Teissier $\mathrm{A}$, Cao-Lormeau VM, Musso D. Evidence of perinatal transmission of Zika virus, French Polynesia, December 2013 and February 2014. Euro Surveill [Internet]. 2014 [cited 2018 Mar. 25]; 19(13):1-4. Available from:https://www.eurosurveillance.org/content/10.2807/1560-7917.ES2014.19.13.20751

7. Mlakar J, Korva M, Tul N, Popović M, PoljšakPrijatelj M, Mraz J, et al. Zika virus associated with microcephaly. N Engl J Med. 2016; 374:951-8. doi: http://10.1056/NEJMoa1600651

8. Franca GVA, Schuler-Faccini L, Oliveira WK, Henriques CM, Carmo EH, Pedi VD, et al. Congenital Zika virus syndrome in Brazil: a case series of the first 1501 livebirths with complete investigation. Lancet. 2016; 388(10047):891-7. doi: https://doi. org/10.1016/S0140-6736(16)30902-3

9. Cauchemez S, Besnard M, Bompard P, Dub T, Guillemette-Artur P, Eyrolle-Guignot D, et al. Association between Zika virus and microcephaly in French Polynesia, 2013-15: a retrospective study. Lancet. 2016; 387(10033):2125-2. doi: 10.1016/S0140-6736(16)00651-6

10. Driggers RW, Ho CY, Korhonen EM, Kuivanen $\mathrm{S}$, Jääskeläinen AJ, Smura $\mathrm{T}$, et al. Zika virus infection with prolonged maternal viremia and fetal brain abnormalities. N Engl J Med. 2016; 374(22):2142-1. doi: 10.1056/NEJMoa1601824

11. Ashwal S, Michelson D, Plawner L, Dobyns WB. Practice parameter: Evaluation of the child with microcephaly (an evidence-based review): report of the Quality Standards Subcommittee of the American Academy of Neurology and the Practice Committee of the Child Neurology Society. Neurology [Internet]. 2009 [cited Feb. 21, 2018]; 73(11):887-7. Available from: https://www.aan. com/PressRoom/home/GetDigitalAsset/8479

12. Brito VRS, Souza FS, Medeiros FAL, Coura AS, Gadelha FHS, França ISX. Incidência de malformação congênita e atenção em saúde nas instituições de referência. Rev Rene [Intenert]. 2010 [citado 2018 mar. 6]; 11(4):29-37. Disponível em: http://www. redalyc.org/articulo.oa?id=324027972003
13. Ministério da Saúde (BR). Secretaria de Atenção à Saúde. Protocolo de atenção à saúde e resposta à ocorrência de microcefalia relacionada à infecção pelo vírus Zika. Brasília: Ministério da Saúde [Internet]. 2015 [citado 2018 Mar. 6]. Disponível em: http://bvsms.saude.gov.br/bvs/publicacoes/ protocolo_resposta_microcefalia_relacionada_ infeccao_virus_zika.pdf

14. Bayer A, Lennemann NJ, Ouyang Y, Bramley JC, Morosky S, Marques Jr ET, et al. Type iii interferons produced by human placental trophoblasts confer protection against Zika virus infection. Cell Host Microbe. 2016; 19(5):705-12. doi:https://doi.org/10.1016/j.chom.2016.03.008

15. Brasil P, Pereira JP Jr, Moreira ME, Nogueira RMR, Damasceno L, Wakimoto $\mathrm{M}$, et al. Zika virus infection in pregnant women in Rio de Janeiro - preliminary report. N Engl J Med. 2016; 375(24):2393-4. doi: 10.1056/NEJMoa1602412

16. Faria NR, Azevedo RDSDS, Kraemer MUG, Souza $\mathrm{R}$, Cunha MS, Hill SC, et al. Zika virus in the Americas: early epidemiological and genetic findings. Science. 2016; 352(6283):345-9. doi: http//dx.doi.org/10.1126/science.aaf5036

17. Zanluca C, Melo VCA, Mosimann ALP, Santos GIV, Santos CND, Luz K. First report of autochthonous transmission of Zika virus in Brazil. Mem Inst Oswaldo Cruz. 2015; 110(4):569-72. doi: http:// dx.doi.org/10.1590/0074-02760150192

18. Miner JJ, Cao B, Govero J, Smith AM, Fernandez E, Cabrera $\mathrm{OH}$, et al. Zika virus infection during pregnancy in mice causes placental damage and fetal demise. Cell. 2016; 165(5):1081-91. doi: https://doi.org/10.1016/j.cell.2016.05.008

19. Calvet G, Aguiar RS, Melo ASO, Sampaio SA, de Filippis I, Fabri A, et al. Detection and sequencing of Zika virus from amniotic fluid of fetuses with microcephaly in Brazil: a case study. Lancet. 2016; 16(6):653-60. doi: https://doi.org/10.1016/ S1473-3099(16)00095-5

20. Yockey LJ, Varela L, Rakib T, Khoury-Hanold W, Fink SL, Stutz B, et al. Vaginal exposure to Zika Virus during pregnancy leads to fetal brain infection. Cell. 2016; 166(5):1247-56. doi: https://doi. org/10.1016/j.cell.2016.08.004 